\title{
Stabilisasi Umpan Balik Output Semi-Global dari Sistem Nonlinear Berfase Non-Minimum
}

\author{
Ansar $^{* 1}$, Janson Naiborhu' ${ }^{2}$ \\ ${ }^{1}$ Universitas Sembilanbelas November Kolaka \\ ${ }^{2}$ Institut Teknologi Bandung \\ e-mail: *11 ansarmawasangka@gmail.com, ${ }^{2}$ janson@itb.ac.id
}

\begin{abstract}
Abstrak
Penelitian ini membahas masalah output feedback dari kelas non linear dengan menggunakan Extended Kalman Filter-Extended High Gain Observer (EKF-EHGO). Dengan menggunakan control output feedback yang memenuhi input state stability (ISS), ketidakstabilan dinamik internal dapat diubah menjadi stabil semi-global dititik asal. Output pada sistem yang berbentuk normal tidak bisa diukur, sehinggaoutput tersebut akan diestimasi dengan menggunakan EKF-EHGO. Solusi masalah ini diilustrasikan dengan contoh
\end{abstract}

Kata kunci: derajar relative ,backstepping, lyapunov, stabilisasi umpan balik

\section{PENDAHULUAN}

Pandang system non linear input tunggal dan output tunggal berikut.

$\dot{x}=f(x)+g(x) \cdot u$

$y=h(x)$

dengan $f(x), g(x)$, dan $\left.h_{\mathrm{f}} x\right)$ fungsi mulus, $\mathrm{u} \in \mathrm{R}$ adalah input, dan $\mathrm{y} \in \mathrm{R}$ adalah output tidak terukur. Misalkan system mempunyai derajat relatif $\rho, 1 \leq \rho<n$ padatitik $x_{0}$. Dengan metodeli nearisasi input-output sistem tersebut dapat dituliskan dalam bentuk normal (Isidori,1997) berikut:

$$
\begin{gathered}
\dot{\eta}=f_{1}(\eta, \xi) \\
\dot{\xi}=\xi_{2} \\
\vdots \\
\dot{\xi}_{\rho}=f_{1}(\eta, \xi, u) \\
y=h(x)=\xi_{1}
\end{gathered}
$$

Salah satu peneliti pertama yang mempelajari tentang sistem nonlinear berfase non-minimum adalah A. Isidori.Dalam makalahnya (Isidori, 2000), dia membuktikan stabilisasi semi-global untuk kelas secara umum dari sistem nonlinear berfase non-minimum dengan asumsi pada keberdaan dinamis stabil dengan mengontrol pada sistem tambahannya. Masalah yang sama di anggap pada (Nazrulla, 2011), dimana robust stabilisasi global akan dicapai dengan asumsi yang sama tetapi dengan Extended high gain observer dikontrol berdasarkan output feedback. Dalam paper (Andrieu,2008) dan (Karagiannis,2005) dipandang sebagai kasus khusus dari persamaan (2), dimana fungsi hanya bergantung sepenuhnya pada lebih besarnya vector $\xi$. Pada paper (Andrieu,2008) memungkinkan adanya gangguan pada model sedangkan paper (Karagiannis,2005) memungkinkan adanya ketidakpastian Model. Kedua-keduanya membutuhkan berbagai kondisi stabilisasi pada dinamika internal. Paper (Marino,2005) dipandang sebagai bentuk system output feedback dan diasumsikan sebagai system nonlinear berfase minimum berhubung dengan output baru, didefinisikan sebagai kombinasi linear dari variabel keadaannya. Paper (Ding, 2005) memberikan solusi masalah stabilisasi dalam

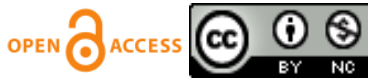


bentuk output feedback dengan zero dinamik linear dengan menggunakan teknik backstepping sehingga observer dinamika linear error akan mencapai hasil semi-global stabilisasi pada titik asal. Hasil lain yang dilaporkan dalam (Hoseini,2010) berkaitan dengan bentuk khusus dari persamaan (2) dengan dinamika internalnya dimodelkan sebagai rantai integrator dengan cara yang sama $\xi$ sebagai dinamikanya. Ini bekerja dengan menggunakan adaptive output feedback kontroler berdasarkan Neural Networks dengan mengamati keadaan linear untuk mencapai batas akhir dari keadaan yang dihadapkan pada model yang tidak pasti.

Pada penelitian ini, menggunakan Extended Kalman Filter Extended High Gain Observer (EKFEHGO) yang disarankan oleh (Boker,2012), untuk menyele-saikan masalah output feedback stabilisasi dari kelas system non linear. Pada (Boker, 2012) menunjukan bahwa dengan menggunakan Extended highgain observer untuk memberikan turunan dari output terukur $\left(\xi_{2}, \ldots, \xi_{\mathbf{n}}\right)$ dan ditambahkan dengan turunan $\xi_{\mathrm{n}}+1$. Keadaan sistem tambahan ini kemudian digunakan untuk memberikan output virtual yang dapat digunakan untuk membuat dinamika internal dapat diamati. Berkat perbedaan skala waktu yang disediakan oleh EHGO, kemudian dengan menggunakan Extended Kalman Filter(EKF) maka output virtual dapat memberikan estimasi keadaan $\eta$ yang ada. Keuntungan dari observer ini adalah memungkinkan untuk merancang feedback control semua variabel dengan keadaan yang ada. Hal ini berbeda dengan hasil yang didapatkan observer sebelumnya, yang mana terbatas pada keadaan parsial feedback dan hanya untuk system berfase minimum. Kontrol output feedback diharapkan memiliki kemampuan untuk mengembalikan dari beberapa trajektori dari system tambahan yang sudah tereduksi, sehingga terbentuk system loop tertutup dengan keadaan Feedback control dan Extended Kalman Filter yang bertindak sebagai observer untuk dinamika internal. Hal ini untuk menyederhanakan desain kontrol output feed back seperti halnya sekarang hanya perlu untuk membentuk respon dari system tambahannya.

Pada (Boker,2012) dipandang sebagai kasus khusus dari persamaan (2) dan $f_{2}(\eta, \xi, u)=f_{3}(\eta, \xi)+f_{4}(\xi, u)$ dapat memberikan sebuah konvergensi lokal untuk EKF-EHGO. Dikasus khusus ini ketika system ini adalah affine pada keadaan internalnya sehingga memberikan konvergensi semi-global. Kontibusi dari system ini untuk menghubungkan kasus khusus ini, dengan menunjukan bahwa ketika observer menggunakan feedback control maka akan mencapai stabilisasi semi-global. Dengan memberikan penggunaan stabilisasi global pada keadaan feedback kontrol yang diasumsikan sebelumnya maka itu memenuhi kondisi input state stability (ISS) yang berkaitan dengan estimasi error dari keadaan internal. Selanjutnya, jelas bahwa system nonlinear ini dianggap sebagai system yang berfase non-minimum.

Dalam Penelitian ini rujukan utamanya adalah (Boker,2013), pada rujukan tersebut dalam melakukan analisis untuk pembahasanya dimulai pada system nonlinear yang sudah berbentuk normal. Berdasarkan rujukan tersebut hal baru yang dilakukan penulis dalam tesis ini adalah penulis dalam melakukan analisis untuk pembahasan dengan hal yang baru. Dimulai dari system nonlinear yang masih mentah kemudian dengan menggunakan metode linearisasi pada sistem nonlinear yang masih mentah tersebut sehingga akan diperoleh sistem yang berbentuk normal. Selanjutnya penulisakan melakukan observer yaitu pada system yang sudah berbentuk normal.

Formulasi masalah yang diajukan pada tesis ini adalah sebagai berikut: Pandang input tunggal, output tunggul sistem nonlinear dengan derajat relatif terdefinisi dengan baik pada sistem yang berbentuk normal berikut

$\dot{\eta}=\mathrm{A}_{1}(\xi) \eta+\varphi_{0}(\xi)$

$\dot{\xi}=\mathrm{A} \xi+\mathrm{B}\left[\mathrm{C}_{1}(\xi) \eta+\alpha(\xi, \mathrm{u})\right]$

$\mathrm{y}=\mathrm{C} \xi$

Dengan $\eta \in \mathrm{R}^{\mathrm{n}-\rho}, \xi \in \mathrm{R}^{\rho}$ merupakan vektor keadaannya, $y$ adalah output terukur dan $u$ adalah input kontrol. Matriks $\mathrm{A}_{\rho x} \rho, \mathrm{B}_{\rho \mathrm{x} 1}$, dan $\mathrm{C}_{1 \mathrm{x} \rho}$ dan $\rho$ yang mempresentasikan derajat relatif. Bentuk normal pada persamaan (4) - (5) adalah bentuk khusus dari persamaan (2), dengan sistem dinamiknya merupakan linear pada keadaaan internal dinamik. Contoh dari sistem ini adalah Translating Oscillator with a Rotating Actuator (TORA) sistem (Wan, 1996). Asumsi 1: 
- Fungsi $\mathrm{A}_{1}(\xi), \varphi_{0}(\xi)$, dan $\alpha(\xi, \mathrm{u})$ merupakan lokal Lipschitz.

- Fungsi $\mathrm{C}_{1}(\xi)$ kontinu terdiferensialkan pada turunan Lipschitz, dengan $\varphi_{0}(0)=0$ dan $\alpha(0,0)=0$.

Tujuan utamanya adalah untuk menstabilkan sistem pada persamaan (4)- (5) pada titik asalnya dengan menggunakan output. Untuk tujuan tersebut, disini digunakan EKF-EHGO untuk memberikan estimasi dari semua keadaannya. Langkah Pengerjaan Masalah yaitu merancang u menggunakan output feedback dari sistem sehingga kestabilan semi-global diperoleh. Karena Internal dinamik pada persamaan (4) tidak stabil untuk $\xi=0$, sehingga dirancang $\xi$ sebagai input agar internal dinamik tersebut stabil asymptotik pada titik asalnya. Masalahnya adalah karena keadaan $\xi$ tidak bisa diukur, oleh karena itu estimasi $\hat{\xi}$ untuk menstabilkan $\hat{\eta}$ dan diharapkan $\hat{\eta}$ sama dengan $\eta$.

Tujuan penelitian adalah memberikan output virtual untuk memberikan estimasi keadaan yang ada dengan menggunakan Extended Kalman Filter (EKF), menyelesaikan masalah output feedback stabilisasi dari kelas sistem no- nlinear berfase non-minimum dengan menggunakan Extended Kalman Filter-Extended High Gain Observer (EKF-EHGO), menggunakan EKF-EHGO untuk menstabilkan sistem yang sudah ber bentuk normal pada titik asalnya dengan mengunakan output terukur, dan Membuat simulasi error dari $(\eta-\hat{\eta})$, simulasi kontrol effort, simulasi sistem reduksinya, dan estimasi untuk setiap keaadan dengan yang berbeda.

\section{METODE PENELITIAN}

Misalkan sistem nonlinear

$\dot{x}=f(x)+G(x) u$

Dengan $f: D \rightarrow R^{n}$ dan $G: D \rightarrow R^{\text {rxo }}$ merupakan fungsi mulus pada domain $\mathrm{D} \subset \mathrm{R}^{\mathrm{n}}$, ikatakan feedback linearizable (atau input-state linearizable) jika terdapat diffeomorphism $T: D \rightarrow R^{n}$ sehingga $D_{z}=T(D)$ masuk kedalam titik asal dan perubahan variabel $z=T(x)$ dengan transformasi sistem persamaan (6) kedalam bentuk normal berikut

$\dot{Z}=A(z)+B \gamma(x)[u-a(x)]$

dengan (A,B) terkontrol dan $\gamma(x)$ nonsingular untuk setiap $x \in D$ (Khalil,2002).

Misalkan input tunggal - output tunggal

$\dot{x}=f(x)+g(x) u$

$y=h(x)$

dengan $f(x), g(x)$ dan $h(x)$ merupakan fungsi mulus , $u \in R$ adalah input, dan $y \in R$

adalah output. Pemetaan $f: D \rightarrow R^{n}$ dan $g: D \rightarrow R^{n}$ merupakan lapangan vektor di D.

Turunan output $y$ diberikan sebagai berikut

$\dot{y}=\frac{\partial h}{\partial x}[f(x)+g(x) u]:=+L_{g} h(x) u$

Dengan

$$
L_{f} h(x)=\frac{\partial h}{\partial x} f(x)
$$

Persamaan (9) dan (10) merupakan operator lie derivative dari $h(x)$ sepanjang $f(x)$ atau sepanjang trakjektory dari sistem $\dot{x}=f(x)$. Contoh penggunaan notasi operator lie derivative sebagai berikut

$L_{g} L_{f} h(x)=\frac{\partial_{f} h(x)}{\partial x} g(x)$

$L_{f}^{2} h(x)=L_{f} L_{f} h(x)=\frac{\partial L_{f} h}{\partial x} f(x)$

$L_{f}^{k} h(x)=L_{f} L_{f}^{k-1} h(x)=\frac{\partial L_{f}^{k-1} h}{\partial x} f(x)$

$L_{f}^{0} h(x)=h(x)$

Jika $L_{g} h(x)=0$ maka $\dot{y}=L_{f} h(x)$, tidak bergantung dari $u$. karena turunan pertama dari $y$ belum menemukan $u$, maka dilanjutkan dengan turunan kedua dari $y$, dinotasikan dengan $y^{(2)}$, dan diperoleh sebagai beikut

$y^{(2)}=\frac{\partial L_{f}^{h}}{\partial x}[f(x)+g(x) u]:=L_{f}^{2} h(x)+L_{g} L_{f} h(x) u$. 
Selanjutnya jika $L_{g} L_{f} h(x)=0$ maka $y^{(2)}=L_{f}^{2} h(x)$, tidak bergantung dari $u$. Karena turunan kedua dari $y$ juga belum menemukan $u$. Dengan proses berulang, diperlihatkan bahwa jika $h(x)$ memenuhi $L_{g} L_{f}^{i-1} h(x)=0, i=1,2, \ldots, \rho-1 ; L_{g} L_{f}^{\rho-1} h(x) \neq 0$.

Dengan $u$ belum ditemukan dari persamaan $y, \dot{y}, \ldots, y^{\rho-1}$ dan $u$ dapat ditemukan di dalam persamaan $y^{\rho}$ dengan koefisien $u$ tidak nol.

$y^{\rho}=L_{f}^{\rho} h(x)+L_{g} L_{f}^{\rho-1} h(x) u$.

Persamaan di atas menunjukkkan dengan jelas bahwa sistem dari input - output linearisasi, karena feedback kontrol keadaan

$u=\frac{1}{L_{g} L_{f}^{\rho-1} h(x)}\left[-L_{f}^{\rho} h(x)+u\right]$

Sehingga reduksi input-output diperoleh

$y^{\rho}=v$

dengan $\rho$ adalah chain integrators. Dalam kasus ini, $\rho$ disebut sebagai derajat relatif dari sistem (Khalil, 2002).

Dibawah ini definisi dari derajat relatif.

\section{Definis 2:}

Sistem nonlinear pada persamaan (8) adalah mempunyai derajat relatif $\rho, 1 \leq \rho \leq n$, dalam daerah $D_{0} \subset D$ jika

$L_{g} L_{f}^{i-1} h(x)=0, i=1,2, \ldots, \rho-1 ; L_{g} L_{f}^{\rho-1} h(x) \neq 0$.

untuk semua $x \in D_{0}$.

Selanjutnya akan dilakukan perubahan variabel dengan mentransformasi persamaan (8) ke dalam sistem yang berbentuk normal berikut.

$\dot{\eta}=f_{0}(\eta, \xi)$

$\dot{\xi}=A_{c} \xi+B_{c} \gamma(x)[u-\alpha(x)]$

$y=C_{c} \xi$

Adapun transformasi (8) kedalam bentuk normal pada persamaan (13)-(15) berdasarkan persamaan berikut

$T(x)=\left[\begin{array}{c}\varphi_{1}(x) \\ \vdots \\ \varphi_{n-\rho}(x) \\ -\frac{-}{h(x)} \\ \vdots \\ L_{f}^{\rho-1} h(x)\end{array}\right]:=\left[\begin{array}{c}\varphi(x) \\ ---- \\ \phi(x)\end{array}\right]=\left[\begin{array}{c}\eta \\ -\frac{-}{\xi}\end{array}\right]$

Dengan $\varphi_{1}$ sampai $\varphi_{n-\rho}$ dipilih sehingga $T(x)$ adalah diffeomorphism pada domain $D_{0} \subset D$ dan

$\frac{\partial \varphi_{1}}{\partial x} g(x)=0$, untuk $1 \leq i \leq n-\rho, \forall \in D$.

Teorema dibawah ini menunjukkan bahwa $\varphi_{1}$ sampai $\varphi_{n-\rho}$ ada, setidaknya lokal.

Teorema : Misalkan sistem pada persamaan (8) dan mempunyai derajat relatif $\rho \leq n$ dalam $D$. Jika $\rho=n$, maka untuk setiap $x_{0} \in D_{0}$, untuk lingkungan $N$ terdapat $x_{0}$ sehingga pemetaan

$T(x)=\left[\begin{array}{c}\varphi_{1}(x) \\ L_{f} h(x) \\ \cdot \\ \vdots \\ L_{f}^{n-1} h(x)\end{array}\right]$

terbatas ke $N$, dan diffeomarphism pada $N$. Jika $\rho<n$ maka untuk setiap $x_{0} \in D_{0}, x_{0}$ dilingkungan $N$ fungsi mulus dan $\varphi_{1}(x), \ldots, \varphi_{n-\rho}(x)$ ada, sehingga persamaan (II. 12) terpenuhi untuk setiap $x_{0} \in D_{0}$ dan pemetaan $T(x)$ dari persamaan (18) terbatas pada $N$, dan diffemorphism pada $N$ (Khalil, 2002). 
Persamaan (13) - (15) merupakan sistem yang berbentuk normal. Bentuk normal tersebut dibagi menjadi 2 bagian yaitu internal dan eksternal, $\xi$ adalah ekstrenal dinamik sedangkan $\eta$ adalah internal dinamik. Jika $\xi=$ 0 maka persamaan berikut

$\dot{\eta}=f_{0}(\eta, 0)$

Internal dinamik (19) disebut zero dinamik. Jika zero dinamik dari sistem stabil asymptotik maka sistem tersebut dikatakan sistem yang berfase minimum, dan jika sistem zero dinamik tidak stabil maka sistem berfase non-minimum. Tujuan merubah sistem kebentuk normal adalah untuk dapat menggunakan hukum kontrol linear pada eksternal dinamik yaitu dengan memilih

$u=\alpha(x)+\beta(x) v$

dengan $(x)=\gamma^{-1}$. Dengan pengambilan imput $u$ seperti pada persamaan (20), maka sistem eksternal dinamik menjadi linear.

Pandang sistem pada persamaan (4) - (5), dengan asumsi ketunggalan dari stabilisasi semiglobal state feedback kontrol dalam bentuk

$\mathrm{u}=\gamma(\eta, \xi)$

Selanjutnya dengan menuliskan kembali vektor keadaan secara keseluruhan

dengan memisalkan $\vartheta=\left[\eta^{\mathrm{T}} \xi^{\mathrm{T}}\right]^{\mathrm{T}}$, sehingga sistem loop tertutupnya dapat dituliskan sebagai persamaan berikut:

$\dot{\vartheta}=\mathbf{f}(\vartheta, \gamma(\eta, \xi))$

Asumsi 2.

$\gamma$ adalah fungsi lokal Lipschitz dalam argumen di atas dan memenuhi

$\gamma(0,0)=0$.

Misalkan $v \in \mathrm{R}^{\mathrm{n}-\rho}$ adalah input yang dapat ditambahkan secara linear pada keadaan $\eta$ sebagai internal dinamiknya sehingga $\mathrm{u}=\gamma(\eta+\mathrm{v}, \xi)$, maka terdapat $\mathrm{V}_{1}(\vartheta)$ yang didefinisikan sebagai fungsi mulus yang definit positif dan fungsi $\alpha_{1}, \alpha_{2}$ berada pada kelas $\kappa_{\infty}$ dan fungsi $\alpha_{3}$, $\zeta$ berada pada kelas $\kappa$ sehingga untuk setiap $\vartheta \in \mathrm{R}^{\mathrm{n}}$, sehingga $\mathrm{V}_{1}(\vartheta)$ memenuhi pertidaksamaan (23) dan pertidaksamaan (24)

$\alpha_{1}(\|\vartheta\|) \leq V_{1}(\vartheta) \leq \alpha_{2}(\|\vartheta\|)$

$\frac{\partial v_{1}}{\partial x} f(\vartheta, \gamma(\eta+v, \xi)) \leq-\alpha_{3}(\|\vartheta\|), \forall\|\vartheta\| \leq \zeta\|\vartheta\|$

Kontrol input harus memenuhi Asumsi 2 tersebut. Catatan : Asumsi 2.2 adalah ekivalen untuk sistem loop tertutup $\dot{V}_{1}=f(\vartheta, \gamma(\eta+v, \xi))$ merupakan bentuk input state stbaility (ISS) dengan $v$ terlihat sebagai input (Ghorbel, 1989).

Pandang sistem persamaan (4) - (5), observer pertama dimulai pada internal dinamiknya dengan sistem tambahan dibawah ini

$\dot{\eta}=\mathrm{A}_{1}(\xi) \eta+\varphi_{0}(\xi)$

$\sigma=\mathrm{C}_{1}(\xi) \eta$

Perhatikan bahwa untuk keadaan $\xi$ dijadikan sebagai input untuk sistem persamaan (25), selanjutnya akan digunakan EHGO untuk mengestimasi keadaan vektor $\xi$ dan signal $\sigma$. Adapun estimasi EHGO yang digunakan untuk persamaan (25) adalah sebagai berikut:

$\dot{\vec{\xi}}=A \hat{\xi}+B[\hat{\sigma}+\alpha(\hat{\xi}, u)]+H(\varepsilon)(y-C \hat{\xi})$

$\dot{\hat{\sigma}}=\varphi_{1}(\widehat{\eta}, \hat{\xi}, u)+\frac{\alpha_{\rho+1}}{\epsilon^{\rho+1}}(y-C \hat{\xi})$

Untuk sistem tambahan pada persamaan (25) memiliki jenis observer dengan memperhatikan bahwa estimasi dari $\widetilde{\eta}=\eta-\hat{\eta}$ akan konvergen ke nol secara asymptotik. Estimasi selanjutnya adalah memilih EKF sebagai observer dalam sistem persamaan (25) sehingga observer internal dinamiknya diperoleh sebagai berikut:

$\dot{\hat{\eta}}=(\hat{\xi}) \hat{\eta}+\phi_{0}(\hat{\xi})+L(t)\left(\hat{\sigma}-C_{1}(\hat{\xi}) \widehat{\eta}\right)$ 
Selanjutnya dengan menggabungkan observer internal dinamik pada persamaan (28) dan persamaan EHGO (26) dan persamaan (27) maka diperoleh observernya untuk keseluruhan adalah sebagai berikut:

$$
\begin{aligned}
& \dot{\hat{\xi}}=A \hat{\xi}+B[\hat{\sigma}+\alpha(\hat{\xi}, u)]+H(\varepsilon)(y-C \hat{\xi}) \\
& \dot{\hat{\sigma}}=\varphi_{1}(\hat{\eta}, \hat{\xi}, u)+\frac{\alpha_{\rho+1}}{\epsilon^{\rho+1}}(y-C \hat{\xi}) \\
& \dot{\hat{\eta}}=(\hat{\xi}) \hat{\eta}+\varphi_{0}(\hat{\xi})+L(t)\left(\hat{\sigma}-C_{1}(\hat{\xi}) \widehat{\eta}\right)
\end{aligned}
$$

Dengan

$\varphi_{1}(\widehat{\eta}, \hat{\xi}, u)=\frac{d}{d t}=C_{1}\left[A_{1}(\xi) \eta+\varphi_{0}(\xi)\right]+\eta \frac{d C_{1}}{d \xi}\left[A \xi+B\left[C_{1}(\xi) \eta+\alpha(\xi, u)\right]\right](\widehat{\eta}, \hat{\xi})$

Pada persamaan (26) gain observer $\mathrm{H}(\xi)$ diberikan seperti berikut:

$H(\xi)=\left[\frac{\alpha_{1}}{\varepsilon_{1}}, \quad . \quad . \quad ., \frac{\alpha_{\rho}}{\varepsilon_{\rho}}\right]^{T}$.

Dengan memilih $\alpha_{1}, \ldots, \alpha_{\rho}, \alpha_{\rho+1}$ pada polinomial $\mathrm{s}^{\rho+1}+\alpha_{1} \mathrm{~s}^{\rho}+\ldots+\alpha_{\rho+1}$ sehingga polinomial tersebut Hurwitz, dan $\varepsilon>0$ parameter bernilai kecil. Pada persamaan (28) $L(t)$ diberikan sebagai berikut:

$L=P C_{1}^{T} R^{-1}$

dan $P$ adalah solusi dari persamaan Riccati

$\dot{P}=A_{1} P+P A_{1}^{T}+Q-P C_{1}^{T} R^{-1} C_{1} P, P\left(t_{0}\right)=P_{0}>0$

$\mathrm{R}(\mathrm{t})$ dan $\mathrm{Q}(\mathrm{t})$ adalah matriks simetris definit positif yang memenuhi pertidaksamaan berikut:

$0 \leq r_{1} \leq R(t) \leq r_{2}$

$0<q_{1} I_{n-\rho} \leq Q(t) \leq q_{2} I_{n-\rho}$

Tujuan dari pertidaksamaan (35) dan (36) untuk mengantisipasi bahwa sistem akan mengalami peaking phenomenon jika sistem nonlinear tidak dibatasi secara global oleh estimasi yang diberikan oleh HGO. Oleh karena itu, solusi efektif yang sederhana untuk masalah ini adalah jika solusi memenuhi keadaan $\xi$ dan $\sigma$ diluar himpunan kompak akan ditarik di sekitar himpunan kompak tersebut, sebelum digunakan observer secara keseluruhan dan kontrolnya (Esfandiari, 1992). Prosedur ini digambarkan dalam contoh yang disajikan dalam Penelitian ini.

Asumsi: Persamaan Riccati (33) memiliki solusi definit positif yang memenuhi pertidaksamaan berikut

$0<q_{1} I_{n-\rho} \leq P^{-1}(t) \leq q_{2} I_{n-\rho}$

Ini sangat penting untuk menstabilkan dari EKF-EHGO sebagai observer yang akan ditunjukkan di sesi selanjutnya.

Selanjutnya akan dibahas sifat-sifat dari sistem loop tertutup dengan mengestimasi error dinamik. Dengan menggunakan persamaan berikut untuk menghitung estimasi error dinamiknya

$\widetilde{\eta}=\eta-\widehat{\eta}$

$X=\frac{\left(\xi_{i}-\hat{\xi}_{i}\right)}{\epsilon^{\rho+1-i}}, 1 \leq i \leq \rho$

$X_{\rho+1}=\left(C_{1}(\xi) \eta\right)-\widehat{\sigma}$

Misalkan

$\phi=\left[X_{1}, X_{2}, \ldots, X_{\rho}\right]$

dan

$D(\varepsilon)=\operatorname{diag}\left[\varepsilon^{\rho}, \varepsilon^{\rho-1}, \ldots, \varepsilon\right]$

Jadi persamaan (39) menjadi

$D(\varepsilon) \phi=\xi-\hat{\xi}$

Selain itu, misalkan

$D_{1}(\varepsilon) X=\left[(\xi-\hat{\xi})^{T}\left(C_{1}(\xi) \eta-\widehat{\sigma}\right)\right]$

Jadi, sistem loop tertutup dengan output feedback kontrol $u=\gamma(\hat{\eta}, \hat{\xi})$ dapat dituliskan dalam bentuk persamaan - persamaan berikut: 
https://jurnal.unsulbar.ac.id/index.php/saintifik

$$
\begin{aligned}
& \dot{\eta}=A_{1}(\xi) \eta+\varphi_{0}(\xi) \\
& \dot{\xi}=A \xi+B\left[C_{1}(\xi) \eta+\alpha(\xi, \gamma(\eta-\widetilde{\eta}, \xi-D(\varepsilon) \phi))\right] \\
& \dot{\tilde{\eta}}=A_{1}(\xi) \eta-A_{1}(\xi-D(\varepsilon) \phi)[\eta-\widetilde{\eta}]+\varphi_{0}(\xi)-\varphi_{0}(\xi-\phi)-L(t)\left[C_{1}(\xi) \eta-X_{\rho+1}-C_{1}(\xi-\right. \\
& D(\varepsilon) \phi)[\eta-\widetilde{\eta}]] \\
& \varepsilon \dot{X}=\Delta X+\varepsilon\left[\overline{B_{1}} \Delta \varphi_{1}+\overline{B_{2}} \bar{\Delta} \alpha\right] \\
& \text { dengan }
\end{aligned}
$$

$$
\begin{aligned}
\Delta & =\left[\begin{array}{cccc}
-\alpha_{1} & 1 & \cdots & 0 \\
-\alpha_{2} & 0 & \cdots & 0 \\
\cdots & \cdots & \cdots & \cdots \\
-\alpha_{\rho} & 0 & \cdots & 1 \\
-\alpha_{\rho+1} & 0 & \cdots & 0
\end{array}\right], \overline{B_{1}}=\left[\begin{array}{l}
0 \\
B
\end{array}\right], \overline{B_{2}}=\left[\begin{array}{l}
B \\
0
\end{array}\right] \\
\Delta \varphi_{1} & =\varphi_{1}(\eta, \xi,(\eta-\widetilde{\eta}, \xi-D(\varepsilon) \phi))-\varphi_{1}(\eta-\widetilde{\eta}, \xi-D(\varepsilon) \phi, \gamma(\eta-\widetilde{\eta}, \xi-D(\varepsilon) \phi))
\end{aligned}
$$

$\bar{\Delta}=\frac{\Delta \alpha}{\varepsilon}$, dan

$\Delta \alpha=\alpha(\xi, \gamma(\eta-\widetilde{\eta}, \xi-D(\varepsilon) \phi))-\alpha(\xi-D(\varepsilon) \phi, \gamma(\eta-\widetilde{\eta}, \xi-D(\varepsilon) \phi))$.

Pada sistem persamaan (41)-(43) merupakan bentuk standar singularly perturbed dan memiliki titik ekuilibrium pada titik asal. Fungsi $\bar{\Delta}$ adalah merupakan fungsi lokal lipschitz dan terbatas atas oleh fungsi affine $\|X\|$ seragam dalam $\varepsilon$ dan matriks $\Delta_{\rho+1 x \rho+1}$ didesain sebagai matriks hurwits.

Teorema (1) berikut ini mendeskripsikan sifat kestabilan pada sis- tem loop tertutup dari output feedback. Pandang sistem loop tertutup pada persamaan (41) - (43). Misalkan asumsi 1-3 dipenuhi dan $\mathrm{M}$ memuat titik asal dan $\mathrm{N}$ semua subhimpunan kompak dari masing-masing $\mathrm{R}^{2 \mathrm{n}-\rho}$ dan $\mathrm{R}^{\rho+1}$. Maka untuk trajektori $(\eta, \xi, \widetilde{\eta}) \mathrm{x}(\hat{\xi}, \hat{\sigma})$ dimulai dalam $M x N$ terdapat $\varepsilon^{*}$ sehingga untuk setiap $0<\varepsilon<\varepsilon^{*}$ maka diperoleh titik asal dari sistem loop tertutup adalah stabil asymptotik dan $\mathrm{M} \times \mathrm{N}$ adalah subset dari region of attraction (wilayah ketertarikan). Titik asal dari sistem persamaan (22) adalah ekponensial stabil maka titik asal dari sistem loop tertutup juga eksponensial stabil.

Bukti: Misalkan dengan memulai pada definisi kondisi dari beberapa awal $(\eta(0), \xi(0), \hat{\eta}(0)) \in \mathrm{M}$ dan $(\hat{\xi}(0), \hat{\sigma}(0)) \in \mathrm{N}$. Sehinga diperoleh $\tilde{\eta}(0)=\eta(0)-\hat{\eta}(0), \phi(0)=\mathrm{D}^{-1}(\varepsilon)[\xi(0)-\hat{\xi}(0)]$ dan $\chi_{\rho+1}=$ $\mathrm{C}_{1}(\eta(0)) \eta-\hat{\sigma}(0)$. Selanjutnya akan digunakan pendekatan perturbasi singular untuk menyelesaikan buktinya. Misalkan $\varepsilon=0$ maka diperoleh $\chi=0$, dengan demikian untuk sistem yang telah direduksi sebagai berikut

$$
\begin{aligned}
& \dot{\eta}=A_{1}(\xi) \eta+\varphi_{0}(\xi) \\
& \dot{\xi}=A \xi+B\left[C_{1}(\xi) \eta+\alpha(\xi, \gamma(\eta-\widetilde{\eta}, \xi))\right] \\
& \dot{\tilde{\eta}}=\left[A_{1}(\xi)-L(t) C_{1}(\xi)\right] \widetilde{\eta}
\end{aligned}
$$

Berdasarkan yang telah didefinisikan sebelumnya, tujuan awalnya akan dibuktikan stabilisasi dari sistem persamaan (44)-(45). Untuk itu, dengan menuliskan kembali persamaan (44)-(45) sehingga dapat ditulis sebagai berikut

$$
\dot{\zeta}=\left[\begin{array}{c}
\dot{\vartheta}=f(\vartheta, \gamma(\eta-\widetilde{\eta}, \xi)) \\
\dot{\bar{\eta}}=\left[A_{1}(\xi)-L(t) C_{1}(\xi)\right] \widetilde{\eta}
\end{array}\right]
$$

Salah satu sifat pembuktian yang digunakan high gain observer adalah mampu untuk mengembalikkan trajektory dari sistem reduksinya. Untuk kasus khususnya, jika $\zeta(\mathrm{t}, \varepsilon)$ solusi dari sistem persamaan (41)-(43) dan $\zeta_{r}(t)$ solusi dari persamaan (46) dimulai dari hasil tersebut dapat dibuktikan dengan menggunakan argumen yang sama digunakan pada pembuktian (Atassi, 1999).

Berdasarkan kondisi dari teorema (1), diberikan sebarang $\delta>0$ terdapat $\varepsilon_{1}^{*}$ sehinggga untuk setiap $0<$ $\epsilon<\varepsilon_{1}^{*}$ maka diperoleh

$$
\left\|\zeta(t, \epsilon)-\zeta_{r}(t)\right\| \leq \delta, \forall t \geq 0
$$


Untuk membuktikkan teorema 2 , di sini interval $[0, \infty]$ dibagi menjadi 3 interval yaitu $[0, \mathrm{~T}(\varepsilon)],[\mathrm{T}(\varepsilon)$, $\left.\mathrm{T}_{3}\right]$ dan $\left[\mathrm{T}_{3}, \infty\right]$, selanjutnya akan dibuktikan teorema 2 untuk setiap interval. Dengan membatasi $\zeta(\mathrm{t}, \varepsilon)$ yang ditunjukkan teorema 1 sebelumnya bahwa $\zeta(\mathrm{t}, \varepsilon)$ asymptotik stabil pada titik asalnya, sehinga dapat disimpulkan bahwa untuk waktu hingga $\mathrm{T}_{3} \geq \mathrm{T}(\varepsilon)$ yang tidak bergantung pada sehingga untuk setiap $0<\epsilon<\varepsilon_{1}^{*}$ diperoleh

$\left\|\zeta(t, \epsilon)-\zeta_{r}(t)\right\| \leq \delta, \forall t \geq T_{3}$

Diketahui bahwa $\zeta(\mathrm{t}, \varepsilon) \Omega_{\mathrm{t}, 2}=\left(\mathrm{V}_{2}(\mathrm{t}, \tilde{\eta}) \leq \mathrm{c}_{2}\right) \forall \in[0, \mathrm{~T}(\varepsilon)]$ dan $\zeta(0)$ adalah interior dari $\Omega_{\mathrm{t}, 2}$ berada pada interval $[0, \mathrm{~T}(\varepsilon)]$, sehingga diperoleh

$\|\zeta(t, \epsilon)-\zeta(0)\| \leq k_{10} t, \forall t \geq[0, T(\varepsilon)]$

dengan interval yang sama $[0, \mathrm{~T}(\varepsilon)]$, dengan cara yang sama sehingga diperoleh pertidaksamaan berikut: $\|\zeta(t, \epsilon)-\zeta(0)\| \leq k_{10} t, \forall t \geq[0, T(\varepsilon)]$

dengan interval yang sama $[0, \mathrm{~T}(\varepsilon)]$, oleh karena itu

$\left\|\zeta(t, \epsilon)-\zeta_{r}(t)\right\| \leq 2 k_{10} t, \forall t \geq[0, T(\varepsilon)]$

Karena $T(\varepsilon) \rightarrow 0$ untuk $\varepsilon \rightarrow 0$, maka diperoleh $0<\varepsilon_{2}<\varepsilon_{1}^{*}$ sehingga untuk setiap $0<\epsilon<\varepsilon_{2}$, maka diperoleh pertidaksamaan berikut

$\left\|\zeta(t, \epsilon)-\zeta_{r}(t)\right\| \leq \delta, \forall t \geq[0, T(\varepsilon)]$

Diatas interval $\left[T\left(\varepsilon, T_{3}\right)\right]$, solusi $\zeta(t, \epsilon)$ memenuhi persamaan (II.35)-(46) dengan $\left\|\zeta\left(T_{3}\right)-\zeta_{r}(T(\varepsilon))\right\| \leq \delta_{1 \varepsilon}$.

Dengan $\delta_{1 \varepsilon} \rightarrow 0$ untuk $\varepsilon \rightarrow 0$, jadi berdasarkan (Khalill, 2002) maka dapat disimpulkan bahwa terdapat $0<\varepsilon_{3}<\varepsilon_{1}^{*}$ dan untuk setiap $0<\epsilon<\varepsilon_{3}$, sehigga diperoleh pertidaksamaan berikut

1. Mengasumsikan bahwa keadaan-keadaan $\xi$, $\eta$, dan $\widetilde{\eta}$ tersedia sebagai tahap untuk mendesain keadaan feedback, dengan demikian desain akan sangat sederhana

2. Menunjukkan bahwa desain kontrol harus memperhatikan estimasi error $\widetilde{\eta}$ dianggap input dari keadaan feedback sistem loop tertutup. Dengan menggunakan persamaan (II.26) dapat disimpulkan sifat-sifat input ini dengan output feedback dapat merancang sebuah kontrol keadaan feedback yang sesuai.

3. Hasil ini dapat memungkinkan untuk tuning (penyetelan) kontrol $u$ agar memenuhi syarat desain keaadan feedback. Desaian feedback kontrol $u$ tersebut dapat dilakukan dengan simulasi pada persamaan (II.39)(II.40) dan memeriksa apakah kontrol yang diberikan memenuhi spesifikasi desain yang diberikan. Sifat ini jarang diperhatikan pada literatur untuk nonlinera kontrol output feedback.

\section{HASIL DAN PEMBAHASAN}

Misalkan sistem nonlinear dengan input tunggal dan output tunggal berikut

$$
\begin{aligned}
& x_{1}=-x_{1}+x_{2} \\
& x_{2}=-x_{1}+2 x_{2}+x_{3}^{2}+u \\
& x_{3}=x_{1}+x_{2}+x_{3} \cos \left(x_{1}\right) \\
& y=x_{1}
\end{aligned}
$$

Turunan output dari sistem diatas sebagai berikut

$y^{\cdot}=-x_{1}+x_{2}$

$y^{\prime \prime}=x_{2}+x_{2}+u$

Sistem ini mempunyai derajat relatif 2 pada $\mathrm{R}^{3}$, karena jumlah derajat relatif lebih kecil dibanding dengan jumlah banyak sistem sehingga tidak terdefinisi dengan baik. Oleh karena itu, sistem diatas akan ditransformasi kedalam sistem yang berbentuk normal. Selanjutnya akan dipilih fungsi $\varphi(\mathrm{x})$ yang akan dijadikan sebagai internal dinamik pada sistem tersebut. Fungsi $\varphi(x)$ harus memenuhi syarat dibawah ini:

$\varphi(0)=\frac{\partial \varphi}{\partial x}, \quad \mathrm{~g}(\mathrm{x})=0$ dan $T(x)=\left[\begin{array}{c}h(x) \\ L_{f} h(x) \\ \varphi(x)\end{array}\right]$ adalah invertibel pada $R^{3}$.

Selanjutnya akan dipilih $\varphi(\mathrm{x})$ yang harus memenuhi turunan parsial berikut : 
$\frac{\partial \varphi}{\partial x_{1}}+\frac{\partial \varphi}{\partial x_{2}}=0$

Dengan memilih fungsi $\varphi(x)=x_{3}$, maka turunan parsial diatas dipenuhi. Oleh karena itu, maka matriks $\mathrm{T}$ (x) adalah

$T(x)=\left[\begin{array}{c}x_{1} \\ -x_{1}+x_{2} \\ x_{3}\end{array}\right]=\left[\begin{array}{ccc}1 & 0 & 0 \\ -1 & 1 & 0 \\ 0 & 0 & 1\end{array}\right]\left[\begin{array}{l}x_{1} \\ x_{2} \\ x_{3}\end{array}\right]$

Karena matriks jacobi $\mathrm{T}(\mathrm{x})$ determinan tidak nol, sehinga $\mathrm{T}(\mathrm{x})$ adalah global diffeomorphism artinya matriks jacobi $\mathrm{T}(\mathrm{x})$ adalah Invertibel. Kemudian sistem bentuk normal diberikan sebagai berikut:

$\dot{\eta}=\xi_{1}+\xi_{2}+\eta \cos \left(\xi_{1}\right)$

$\dot{\xi}_{1}=\xi_{2}$

$\dot{\xi}_{2}=\xi_{2}+\eta^{2}+u$

$y=\xi_{1}$

Dengan membuat $\xi=0$ sehingga internal dinamik menjadi $\dot{\eta}=\eta$ disebut zero dinamik. Karena zero dinamiknya tidak stabil jadi sistem tersebut adalah berfase non-minimum. Pertama yang dilakukan adalah mendesain keadaan feedback kontrol dengan memeriksa apakah kondisi asumsi 2 terpenuhi. Selanjutnya akan digunakan teknik backstepping untuk dijadikan sebagai desain kontrol. pada persamaan (49)-(52) dan persamaan tersebut merupakan sistem yang sudah berbentuk normal (Khalil, 2002). Dari prosedur backstepping yang dijalankan tersebut tujuannya adalah untuk menentukan Feedback kontrol u sehingga pada persamaan (49)-(52) akan stabil asymptotik pada titik asalnya dengan berdasarkan feedback kontrol $u$ yang diperoleh dari teknik backstepping. Sekarang akan dipilih fungsi lyapunov yang digunakan sebagai dasar untuk memeriksa apakah feedback kontrol $u$ yang diperoleh memenuhi kondisi dari properti Input state stability (ISS).

Sekarang akan dilakukan untuk menentukan desain feedback kontrol u yang akan dimulai dari internal dinamik pada persamaan (49) berikut

$\dot{\eta}=\xi_{1}+\xi_{2}+\eta \cos \left(\xi_{1}\right)$

Selanjutnya akan didesain feedback kontrol dengan memilih $\xi_{1}$ sebagai input virtual dan dijadikan sebagai proses untuk mendesain keadaan feedback kontrol dengan memilih $\xi_{1}=\psi\left(\xi_{2}, \eta\right)$ yang stabil pada titik asal $\left(\xi_{2}, \eta\right)=(0,0)$ dengan

$\xi_{1}=\psi\left(\xi_{2}, \eta\right)=-\left(\xi_{2}+k \eta\right), k>1$

Sehingga sistem tersebut dengan mensubtitusikan input virtual diatas sehingga diperoleh sistem berikut:

$$
\dot{\eta}=-k \eta+\eta \cos \left(-\left(\xi_{2}+k \eta\right)\right)
$$

Selain itu dengan memilih kandidat fungsi lyapunov $\mathrm{V}(\eta)=\frac{1}{2} \eta^{2}$ sehingga diperoleh turunan dari fungsi lyapunov sebagai berikut:

$\mathrm{V}(\eta)=\frac{1}{2} \eta^{2}$

$\dot{V}(\eta)=\eta \dot{\eta}=\eta\left(-k \eta+\eta \cos \left(-\left(\xi_{2}+k \eta\right)\right)\right) \leq-k \eta^{2}+\eta^{2}=-(\mathrm{k}-1) \eta^{2}, \eta \in R, k>1$

Berdasarakan pertidaksamaan diatas, karena turunan fungsi lyapunov dari $\dot{V}(\eta) \leq 0$ untuk setiap $\eta \in$ R. Jadi terbukti bahwa titik asal dari sistem $\eta^{\circ}=-k \eta+\eta \cos (-(\xi 2+k \eta))$ adalah asymptotik stabil. Pada backstepping dengan menggunakan perubahan variabel, sekarang misalkan $\mathrm{z}_{1}=\eta_{2}-\psi\left(\xi_{1}, \eta\right)=\xi_{1}+\xi_{2}+\mathrm{k} \eta$, sehingga dengan perubahan variabel tersebut maka untuk transformasi sistem ke dalam bentuk sistem nonlinear berikut.

$$
\begin{aligned}
& \dot{\eta}=-k \eta+\eta \cos \left(-\left(\xi_{2}+k \eta\right)\right)+z_{1} \\
& \dot{z_{1}}=2 \xi_{2}+\eta^{2}-k^{2} \eta+k \eta \cos \left(-\left(\xi_{2}+k \eta\right)\right)+k z_{1}+u
\end{aligned}
$$

Pilih

$V_{c}(\xi, \eta)=\frac{1}{2} \eta^{2}+\frac{1}{2} z_{1}^{2}$ 
https://jurnal.unsulbar.ac.id/index.php/saintifik

Dengan Vc sebagai kandidat fungsi lyapunov komposite, sehingga diperoleh turunan fungsi lyapunov komposite sebagai berikut:

$V_{c}(\xi, \eta)=\frac{1}{2} \eta^{2}+\frac{1}{2} z_{1}^{2}$

$\dot{V}_{c}(\xi, \eta)=\eta \dot{\eta}+z_{1} \dot{z}_{1}=\eta\left(-k \eta+\eta \cos \left(-\left(\xi_{2}+k \eta\right)\right)+z_{1}\right)+z_{1}\left(2 \xi_{2}+\eta^{2}-k^{2} \eta+k \eta \cos \left(-\left(\xi_{2}+\right.\right.\right.$

$\left.k \eta))+k z_{1}+u\right) \leq-(\mathrm{k}-1) \eta^{2}+z_{1}\left(2 \xi_{2}+\eta^{2}-\left(k^{2}-1\right) \eta+k \eta \cos \left(-\left(\xi_{2}+k \eta\right)\right)+k z_{1}+u\right)$

Pilih

$u=-2 \xi_{2}-\eta^{2}+\left(k^{2}-1\right) \eta-k \eta \cos \left(-\left(\xi_{2}+k \eta\right)\right)-2 k z_{1}=-2 \xi_{2}-\eta^{2}+\left(k^{2}-1\right) \eta-$

$k \eta \cos \left(-\left(\xi_{2}+k \eta\right)\right)-2 k\left(\xi_{1}+\xi_{2}+k \eta\right)$

Sehingga diperoleh

$$
\dot{V}_{c} \leq-(\mathrm{k}-1) \eta^{2}-k z_{1}^{2}=\leq-(\mathrm{k}-1) \eta^{2}-k\left(\xi_{1}+\xi_{2}+k \eta\right)^{2}
$$

Berdasarkan pertidaksaman diatas, karena turunan fungsi lyapunov komposite dari $\dot{\mathrm{V}}_{\mathrm{c}}(\xi, \eta) \leq 0$ untuk setiap $\eta \in \mathrm{R}$ dan untuk setiap $\xi \in \mathrm{R}^{2}$. Jadi terbukti bahwa sistem tersebut pada titik asal adalah asymptotik stabil. Jelas bahwa asumsi 2.1 dan 2.2 terpenuhi, sehingga dapat disimpulkan bahwa pada titik asal dari output feedback sistem loop tertutup adalah asymptotik stabil. Adapun pembuktiannya dapat dilihat pada gambar III.1 dibawah ini, pada gambar III.1 dibawah ini memperlihatkan bahwa untuk setiap keadaan pada sistem nonlinear yang berbentuk normal tersebut akan asymptotik stabil pada titik asalnya dengan desain feedback kontrol $u$ yang diperoleh melalui prosedur teknik backstepping.
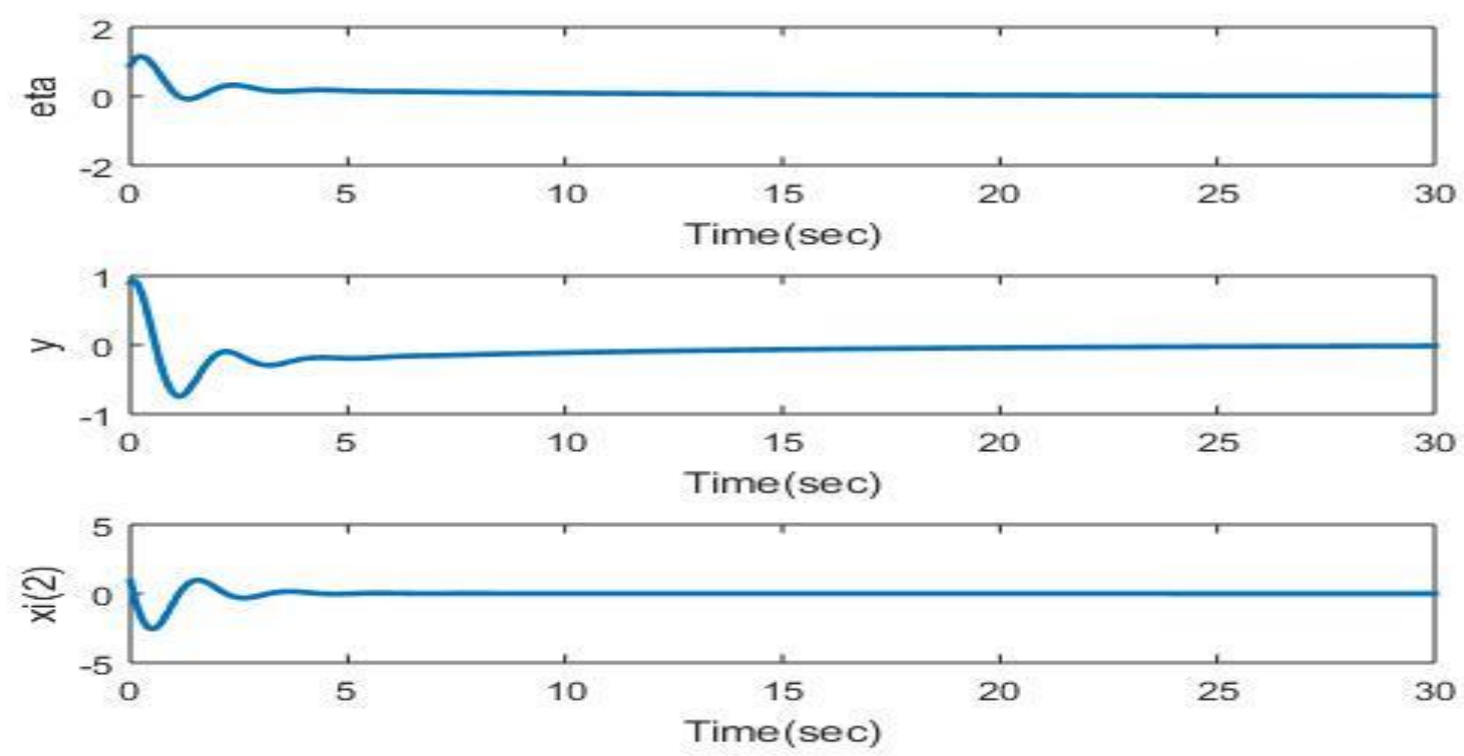

Gambar 1 Respon dari output y, keadaan $\xi_{2}$ dan keadaan internal $\eta$ terhadap sistem dengan output feedback

Secara keseluruhan untuk mendesain observer yang sesuai dengan prosedur sebelumnya maka persamaan sistem observer sebagai berikut 
https://jurnal.unsulbar.ac.id/index.php/saintifik

$$
\begin{aligned}
& \dot{\bar{\xi}}=\widehat{\xi}_{2}+\frac{\alpha_{1}}{\varepsilon}\left(y-\widehat{\xi}_{1}\right) \\
& \dot{\xi_{2}}=\widehat{\xi}_{2}+\widehat{\sigma}+\frac{\alpha_{2}}{\varepsilon^{2}}\left(y-\widehat{\xi}_{1}\right) \\
& \quad \dot{\hat{\sigma}}=\varphi_{2}(\eta, \xi)+\frac{\alpha_{3}}{\varepsilon^{3}}\left(y-\widehat{\xi}_{1}\right) \\
& \dot{\hat{\eta}}=\widehat{\xi}_{1}+\widehat{\xi}_{2}+\hat{\eta} \cos \left(\widehat{\xi}_{1}\right)+L(t)(\hat{\sigma}-\widehat{\eta})
\end{aligned}
$$

dengan $\varphi_{2}(\eta, \xi)=\left(\widehat{\xi}_{1}+\widehat{\xi}_{2}+\widehat{\eta} \cos \left(\widehat{\xi}_{1}\right)\right)$. Untuk observer $\mathrm{L}(\mathrm{t})$ adalah diberikan pada persamaan (32) dan (33) dengan memperhatikan $\mathrm{A}_{1}$ dan $\mathrm{C}_{1}$ diberikan oleh $A_{1}=\cos \left(\widehat{\xi}_{1}\right)$ dan $C_{1}=1$. $\mathrm{Q}=6, \mathrm{R}=1$, $\alpha_{1}=3, \alpha_{2}=3, \alpha_{3}=1, \mathrm{P}(0)=0.9, \eta(0)=0.1, \xi_{1}(0)=0.5, \xi_{2}(0)=0, \hat{\xi}_{1}(0)=0.8, \hat{\xi}_{2}(0)=0.3$, $\hat{\eta}(0)=0.9, \hat{\sigma}(0)=0.9$. Karena Demontrasi yang ditunjukkan untuk memandang kendala fisik pada sistem atau sebagai hasil keadaaan dengan menggunakan feedback kontrol, keadaan $\eta$ memiliki himpunan $\{-15,10\}$.

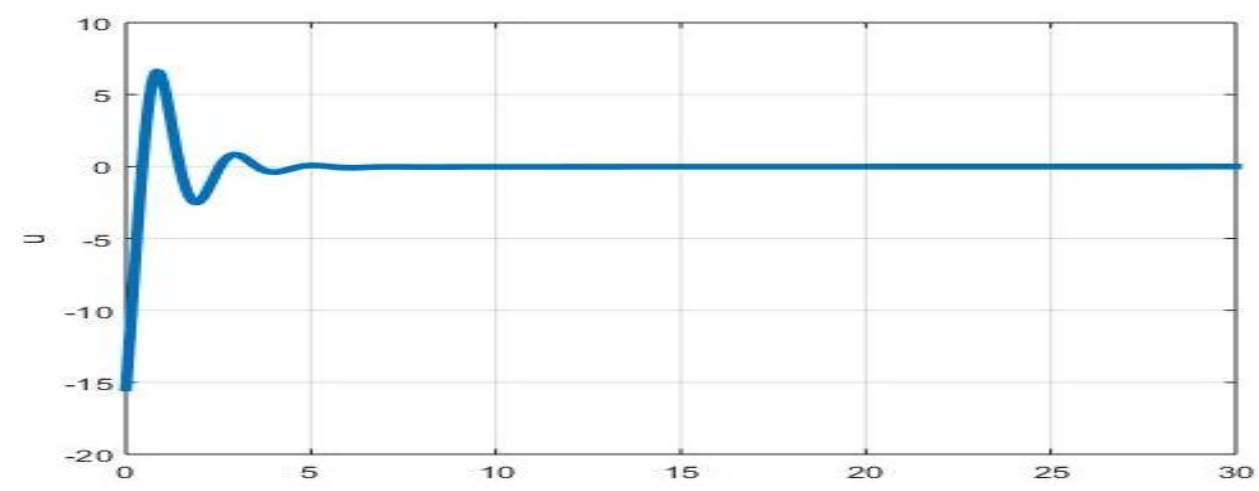

Gambar 2 menunjukaan kontrol yang diperlukan untuk menstabilkan sistem yang sudah berbentuk normal.

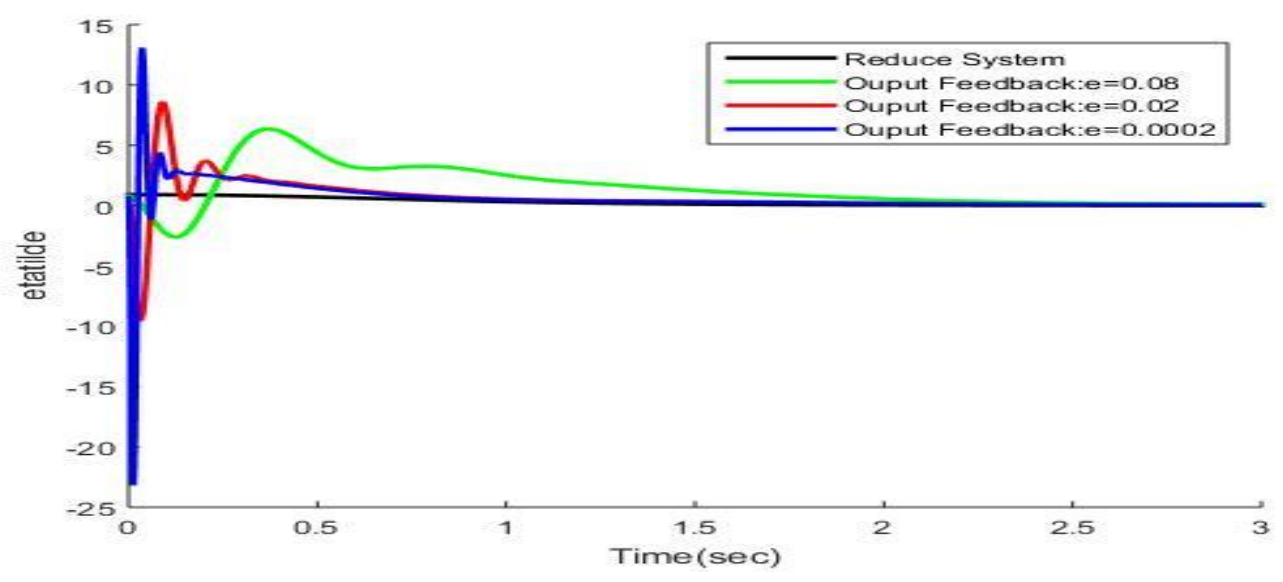

Gambar 3 menunjukkan respon dari sistem $\dot{\tilde{\eta}}=\left[A_{1}-L(t) C_{1}\right] \widetilde{\eta}$, yang dimulai dari $\widetilde{\eta}(0)=0.4$ sebagai bagian sistem yang direduksi oleh persamaan (47). Untuk $\varepsilon$ cukup kecil maka akan lebih dekat dengan trajektory output feedback menjadikan lebih dekat dengan sistem direduksi. 
https://jurnal.unsulbar.ac.id/index.php/saintifik
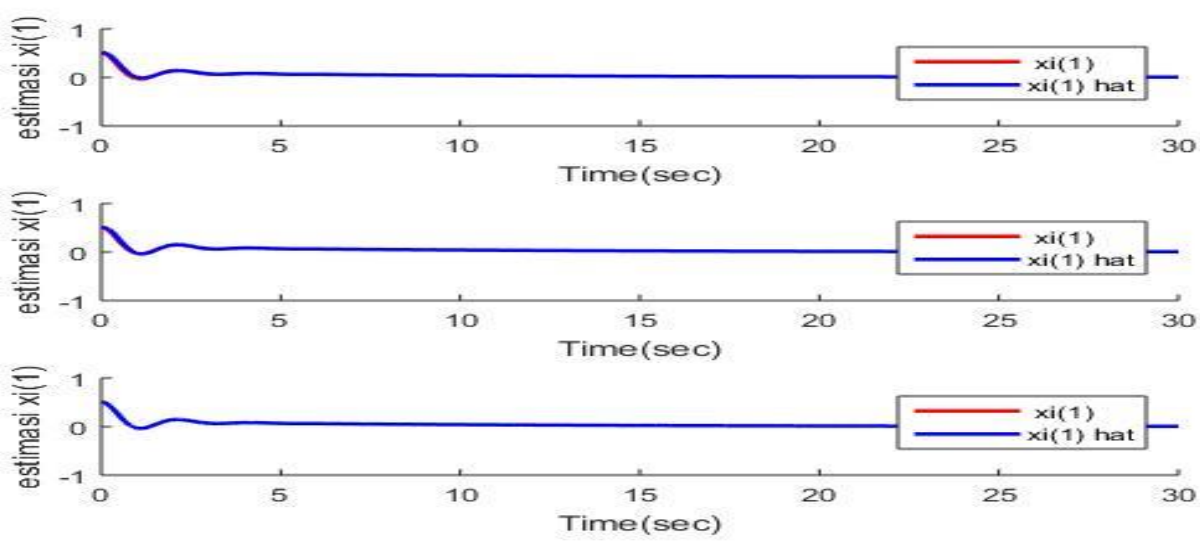

Gambar 4 Estimasi keadaan $\xi_{1}$ dengan memilih $\varepsilon$ yang beragam yaitu $\varepsilon=0.3, \varepsilon=0.27$, dan
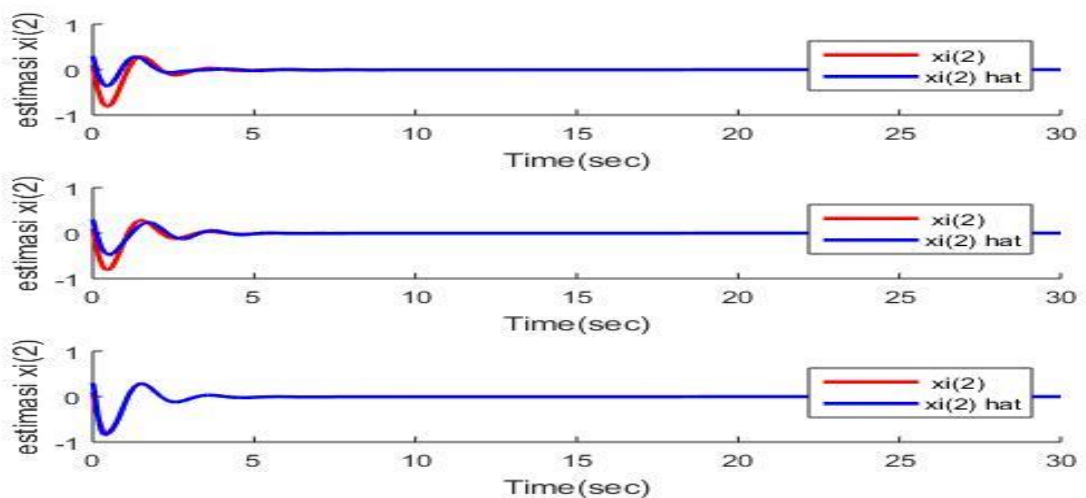

$\varepsilon=0.1$

Gambar 5 Estimasi keadaan $\xi_{2}$ dengan memilih $\varepsilon$ yang beragam yaitu $\varepsilon=0.3, \varepsilon=0.27$, dan $\varepsilon=0.1$
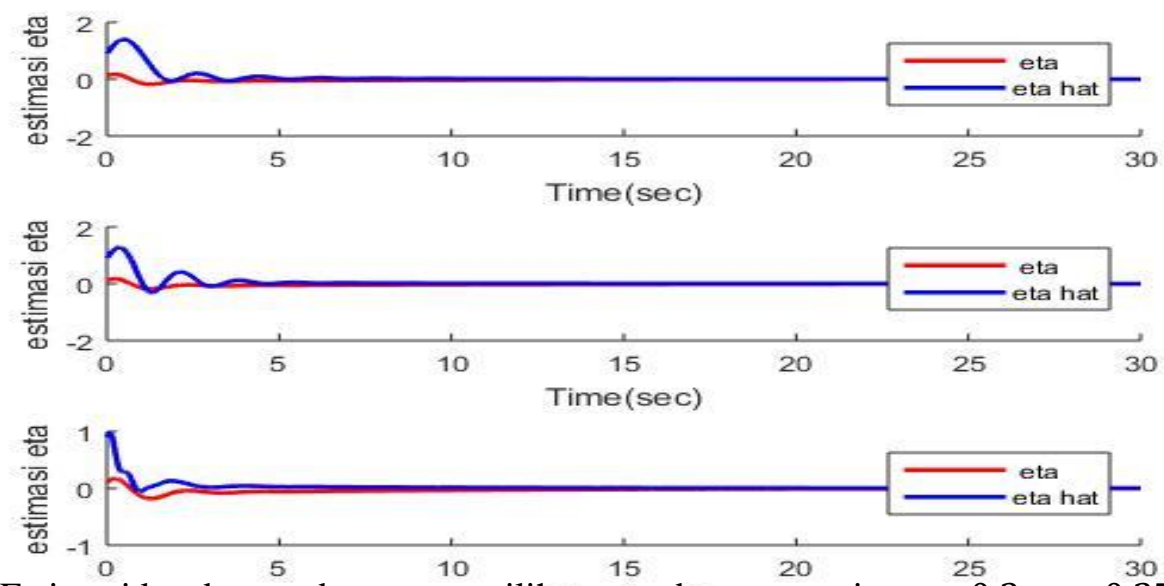

Gambar 6 Estimasi keadaan $\eta$ dengan memilihrenyeang beragam yaitu $\varepsilon=0.3, \varepsilon=0.27$, dan $\varepsilon=0.1$ 
Pada gambar III.4, gambar III.5 dan gambar III.6 diatas menjelaskan ilustrasidari observer yang diberikan oleh EKF-EHGO pada sistem yang sudah berbentuk normal. Tujuan dari observer yang diberikan adalah untuk mengestimasi semua keadaan pada sistem tersebut dan harapannya adalah selisih atau error antara keadaan sesungguhnya dengan keadaan estimasi adalah asymtotik stabil ke nol. Jadi kesimpulannya adalah dengan $\varepsilon$ yang berbeda tentu akan memberikan ilustrasi yang berbeda, jika semakin kecil maka setiap masing - masing keadaan estimasi $\hat{\xi}_{1}, \hat{\xi}_{2}$, dan $\hat{\eta}$ akan lebih dekat dengan masing - masing keadaan $\xi_{1}, \xi_{2}$ dan $\eta$ dengan kondisi nilai awal yang sama setiap $\varepsilon$ tersebut.

\section{KESIMPULAN}

Adapun kesimpulan pada tesis ini sebagai berikut mempresentasikan kontrol strategi output feedback ini yang didasarkan pada observer EKF-EHGO, feedback kontrol yang digunakan memenuhi kondisi ISS dan ketika mengestimasi error dinamik feedback kontrol digunakan untuk menstabilkan keadaanya secara asymptotic, memberikan kestabilan semi-global pada sistem loop tertutup dari kelas sistem nonlinear yang berfase non-minimum dengan kondisi keadaanya akan stabil asymptotik pada titik asalnya, membuktikan bahwa stability recovery dari sistem loop tertutup akan stabil asymptotik pada titik asal dengan kondisi nilai awal sesuai, dan dengan desain feedback kontrol untuk seluruhnya dan kemudian menggunakan EKF-EHGO untuk estimasi dari keadaan, semakin kecil yang dipilih maka semakin kecil error antara keadaan sesungguhnya dengan estimasi keadaannya dengan kondisi nilai awal yang sama

\section{DAFTAR PUSTAKA}

Andrieu, V. and Praly, L. (2008). Global asymptotic stabilization for nonminimum phase nonlinear systems admitting a strict normal form. IEEE Transactions on Automatic Control. vol. 53, no. 5, pp. 1120-1132.

Atassi, A., and Khalil, H. (1999). A separation principle for the stabilization of a class of nonlinear systems. IEEE Transactions on Automatic Control, vol. 44, no. 9, pp. 1672-1687

Boker, A. and Khalil, H. (2013). Semi-Global Output Feedback Stabilisai Dari Ke- las Sistem Nonlinear Berfase Non-Minimum. American Control Conference (ACC) Washington, DC, USA, June 17-19, 2013

Boizot, N., Busvelle, E., and Gauthier, J. (2010). An adaptive high-gain observer for nonlinear systems. Automatica, vol. 46, no. 9, pp. 1483-1488

Ding, Z. (2005). Semi-global stabilisation of a class of non-minimum phase non- linear outputfeedback systems. IEE proceedings in Control Theory and Ap- plications. vol. 152, no. 4.IET, 2005 pp. $460-464$.

Esfandiari, F., dan Khalil, H. (1992). Output feedback stabilization of fully lineari- zable systems. International Journal of Control. vol. 56, no. 5,pp.1007-1037

Ghorbel, F., Hung, J., and Spong, M. (1989). Adaptive control of flexiblejoint ma- nipulators. IEEE Control systems Magazine. vol. 9, no. 7, pp. 9-13, 1989

Hoseini, M., Farrokhi, M., and Koshkouei, A. (2010). Adaptive neural network ou- tput feedback stabilization of nonlinear non-minimum phase systems. Inter- national journal of adaptive control and signal processing, vol. 24, no.1, pp.

$65-82$ 
Isidori, A. (2000). A tool for semi-global stabilization of uncertain non-minimum phase nonlinear systems via output feedback. IEEE Transactions on Auto- matic Control , vol. 45, no. 10, pp. 18171827

Isidori, A. (1997). Nonlinear control systems. Springer-Verlag: New York, Inc. Karagiannis, D., Jiang, Z., Ortega, R., and Astofi, A. (2005). Output-feedback sta-

bilization of a class of uncertain non-minimum-phase nonlinear systems. Au-

tomatica. vol. 41, no. 9, pp. 1609-1615

Khalil, H. (2002). Nonlinear systems. Printice-Hall.

Marino, R. and Tomei, P. (2005). A class of globally output feedback stabiliza- ble nonlinear nonminimum phase systems. IEEE Transactions on Automatic Control. vol. 50, no. 12, pp. 20972101

Nazrulla, S., and Khalil, H. (2011). Robust stabilization of non-minimum phase nonlinear systems using extended high-gain observers. IEEE Transactions on Automatic Control. vol. 56, no. 4, pp. 802813 